\title{
Bioactive composites for bone tissue engineering
}

\author{
K E Tanner \\ School of Engineering, James Watt South Building, University of Glasgow, Glasgow, G12 8QQ, \\ UK \\ Corresponding Author: \\ Professor K.E. Tanner, School of Engineering, James Watt South Building, University of Glasgow, Glasgow, G12 \\ 8QQ, UK \\ Phone: $\quad+44-141-330-3733$ \\ Fax: $\quad+44-141-330-4343$ \\ e-mail: $\quad$ elizabeth.tanner@glasgow.ac.uk
}

\begin{abstract}
One of the major challenges of bone tissue engineering is the production of a suitable scaffold material. In this review the current composite materials options available are considered covering both the methods of both production and assessing the scaffolds. A range of production routes have been investigated ranging from the use of porogens to produce the porosity through to controlled deposition methods. The testing regimes have included mechanical testing of the materials produced through to in vivo testing of the scaffolds. While the ideal scaffold material has not yet been produced, progress is being made.
\end{abstract}

Keywords: Bioactive, biodegradable, biomechanical properties, composites, porosity, tissue engineering scaffold

\section{INTRODUCTION}

The requirements for scaffold materials for bone tissue engineering are easily defined however our ability to produce such materials is limited. The scaffold needs to contain both macropores, 300$400 \mu \mathrm{m}$ across, to allow osteons or bone spicules to grow into the scaffold [1] and micropores to encourage nutrient supply and the removal of waste products $[2,3]$. The material needs to be bone bioactive, that is to encourage bone ingrowth, and to degrade, at an appropriate rate, to allow the newly formed tissue gradually to replace the scaffold, both as mechanical structure and in terms of space occupied. Finally, and this is where most current materials fail, the material needs mechanical properties that allow the device to be implanted without failing thus allowing the patient to use the implanted area without mechanical protection such as a cast but also to allow sufficient loading of the newly formed tissue to stimulate mechanically the osteoblasts. As yet no one has reported a material that fulfils all these requirements.

However, one group of materials that do attempt fulfil many of these requirements are composites of degradable polymers reinforced with ceramics, glass-ceramics or bioglasses. If the polymer is biodegradable and the ceramic, glass-ceramic or bioglass phase is degradable or metabolised by the body then the degradation requirement is fulfilled.
The use of ceramics or glass-ceramics can both stiffen and strengthen a low modulus and lwo strength polymer and increase the bioactivity of the composite [4]. Finally a range of techniques can be used to develop a porous structure, including porogens that are processed into the material and then develop the required porosity either by generating gas bubbles or by being dissolved out and leaving spaces. Other methods of generating porosity include depositing the material with gaps between individual material fibres such as electrospinning and fused laser deposition.

This review will consider only composite scaffolds, as the use of composites allows the combination of bioactive ceramics or glasses, which are stiff and bioactive, but normally are too brittle for load bearing applications, with polymers which are ductile but do not have sufficient stiffness or biological activity, for mechanically successful bone implantation. These composite scaffolds can be produced by a variety of methods including manufacturing a composite material in a porous form, taking a brittle ceramic scaffold and toughening it by coating with a polymer or taking a tough polymeric scaffold and coating it with a bioactive layer, using a technique such as soaking in supersaturated simulated body fluid (SBF) or calcium and phosphate containing solutions. The most commonly used SBF is SBF- 
K9 developed by Kokubo et al. [5] to test the relative bone bioactivity of ceramics and glass ceramics. SBF-K9 has very similar ionic concentrations to blood plasma, but no protein content, the rate at which it deposits on a bone bioactive material usually is considered to be indicative of the rate of incorporation in the body in vivo and deposition does not occur on non-bone bioactive materials [6]. If, however, the SBF strength is increased then an hydrated carbonate apatite (HCA) layer can be deposited on a bioinert surface rendering it bioactive [7]. The artificial polymers used include the polylactic acid (PLA), polyglycolic acid (PGA) and polyhydroxybuterate (PHB) and various of their co-polymers and polymer blends. From natural sources there are two major polymers, collagen, the main connective tissue of the body, while chitosan, purified from the shells of prawns and other shellfish is a by-product of the food industry. Collagen used as a biomaterial is usually purified from bovine tendon, although bone and dentine are other potential sources [8]. Chitosan is biodegradable and the mechanical properties can be altered by the degree of acetylation, furthermore it can absorb and release various cytokines and other bioactive molecules, thus changing the biological response to the implanted material $[9,10]$. The fillers used include tricalcium phosphate $\left(\mathrm{Ca}_{3}\left(\mathrm{PO}_{4}\right)_{2}-\mathrm{TCP}\right)$, a degradable calcium phosphate related to hydroxyapatite $\left(\mathrm{Ca}_{10}\left(\mathrm{PO}_{4}\right)_{6}(\mathrm{OH})_{2}-\mathrm{HA}\right)$, which in turn is the stiochoimetric version of bone mineral, bioglasses of various types such as Bioglass ${ }^{\circledR} 45 \mathrm{~S} 5$ and other glass ceramics including A-W glass ceramic. When considering ceramic-polymer composite formulation the factor of typically three difference in the density of the ceramic and the polymer phases leads to major differences in the filler content when defined as weight percentage or volume percentage.

This review will consider the methods of producing the required porosity and the materials used. The testing regimes from in vitro bioactivity, to in vitro cell culture and finally in vivo testing will be reviewed.

\section{POROGEN MANUFACTURED SCAFFOLDS}

Porogens, or substances that produce porosity, are available in three basic types, those that dissolve, those that melt and those that produce gas bubbles. The two most commonly used soluble porogens are sugar and salt, both of which are available in a variety of sizes to produce a suitable range of pore sizes and are easily dissolved in water. Furthermore the products are not cytotoxic, except in very high doses, so any remaining porogen after dissolution which subsequently leaches out in vivo, will not generate a cytotoxic response. The second group are the waxes which are removed by melting, these have been used less often, probably due to concerns over any wax remaining in a closed cell. Some carbon dioxide producing chemical reactions based porous scaffolds have been produced. Porogens have been used to manufacture PLA, PGA and PHB based scaffolds.

Polylactic acid scaffolds produced using porogens Charles-Harris et al., [11,12] produced porous PLDLA reinforced with 20 or $50 \mathrm{wt} \%$ calcium phosphate glass scaffolds by solution casting using sodium chloride salt particles to produce porosity. After dissolving the PLDLA in chloroform the $\mathrm{P}_{2} \mathrm{O}_{5}-\mathrm{CaO}-\mathrm{Na}_{2} \mathrm{O}-\mathrm{TiO}_{2}$ based glass and salt were added and the chloroform was allowed to evaporate and then the salt dissolved out. They found increased protein absorption with increasing glass content. They subsequently cultured cells from the MG63 osteoblast cell line on the scaffolds in both static and dynamic (perfusion) environments [13]. They found increases in cell proliferation and differentiation on the glass containing composite than the plain PLDLA. They found that the perfusion regime increased the cell seeding efficiency and produced more even cell distribution. For $95 \%$ porous scaffolds they were able to obtain scaffold stiffnesses up to $217 \mathrm{kPa}$ by optimising the size of the glass and salt particles. They do comment that at this level of porosity the glass filler particles do not act to stiffen or strengthen the polymer but rather act as defects due to the lack of bonding between the polymer and the glass particles. The smooth surfaces of glass particles commonly leads to a low strength interface between the filler and matrix and thus low mechanical properties [14]. While chemical coupling agents have been used in non-degradable composites [15] their use in degradable composites such as tissue scaffolds leads to additional concerns involving their degradation products.

Some researchers have relied on the natural structure of coral to provide required macro and micro pore size and shape for bone scaffold materials. Kusmanto et al. [16] used a naturally porous red coralline alga, Phymatolithon calcareum, with mean pore size of $7 \mu \mathrm{m}$ to produce the required macropores. Pyrolysis was used to convert the coral to $\mathrm{CaO}$ and then to $\mathrm{CaCO}_{3}$ and finally hydrothermal conversion was used to transform the material to microporous HA which was mixed with PCL to produce the composite. Salt particles were used as the porogen to produce macropores. SEM showed that the HA particles retained the microporosity of the alga 
precurser and that the macroporosity depended on the size of the salt particles. For a given porosity level the stiffness and strength were higher when larger salt particles were used, that is the pore size was increased. Cell culture showed the materials to be biocompatible with cells from the MG63 osteoblast-like cell line able to interact with the micropores in the HA phase (Figure 1).

Polylactic acid-glycolic acid scaffolds produced using porogens

Kim et al. [17] compared composite scaffolds of PLGA reinforced with HA made using gas foaming and porogen leaching with those made using the more conventional solvent casting and porogen leaching. The solvent casting-porogen leaching samples had open cells $100-200 \mu \mathrm{m}$ in diameter while gas foaming lead to both open cells of similar size produced by the dissolution of the salt particles and closed cells $10-45 \mu \mathrm{m}$ in diameter, which thus increased the average porosity from 85 to $91 \%$. However, the gas foamed samples had twice the compressive modulus and 13 times the tensile modulus to the solution cast scaffolds. Cell culture studies, using rat calveria osteoblasts, showed that the addition of the HA increased the cell number and calcification from unfilled solvent case PLGA and yet higher activity was found on the gas foamed samples. When implanted subcutaneously in nude mice a similar trend was seen to the in vitro cells culture studies.

Guarino and Ambrosio [18] used filament winding to produce scaffolds of drawn PLA fibres in a matrix of PCL reinforced with up to 26vol\% $\alpha$-TCP using salt particles to produce porosity. The PLA fibres were drawn through a solution of PCL in dimethylacetamide with $\alpha$-TCP and salt particles $300-500 \mu \mathrm{m}$ in diameter suspended in the solution. The coated PLA fibres were then filament wound to produce the material and soaked in water for 24 hours to leach out the salt particles. This production method lead to tubular specimens of $3 \mathrm{~mm}$ internal diameter, $7 \mathrm{~mm}$ external diameter with $80 \%$ porosity consisting of macropores $100-400 \mu \mathrm{m}$ in diameter connected by micropores.

The addition of the $\alpha$-TCP increased the modulus from $0.49 \pm 0.04 \mathrm{MPa}$ to $2.21 \pm 0.24 \mathrm{MPa}$ in the initial linear region of the stress-strain curve and the material behaved as a typical foam, gradually compacting as the load increased.

\section{Other porogen produced scaffolds}

Li and colleagues $[19,20]$ manufactured scaffolds of PHBV reinforced with up to $20 \mathrm{wt} \%$ of a bioglass or wollastonite glass also using salt leaching to generate the requisite porosity. For porosities of 77 to $80 \%$, the addition of the bioglass increased the yield strength from $0.16 \pm 0.03$ to $0.41 \pm 0.09 \mathrm{MPa}$. Pore sizes were between 30 and $300 \mu \mathrm{m}$. Soaking in SBF showed the $20 \mathrm{wt} \%$ bioglass composite to be potentially bioactive, although the water contact angle decreased with increasing bioglass content. The $\mathrm{pH}$ of the solution remained constant for the first 8 days when there was no reinforcing phase and

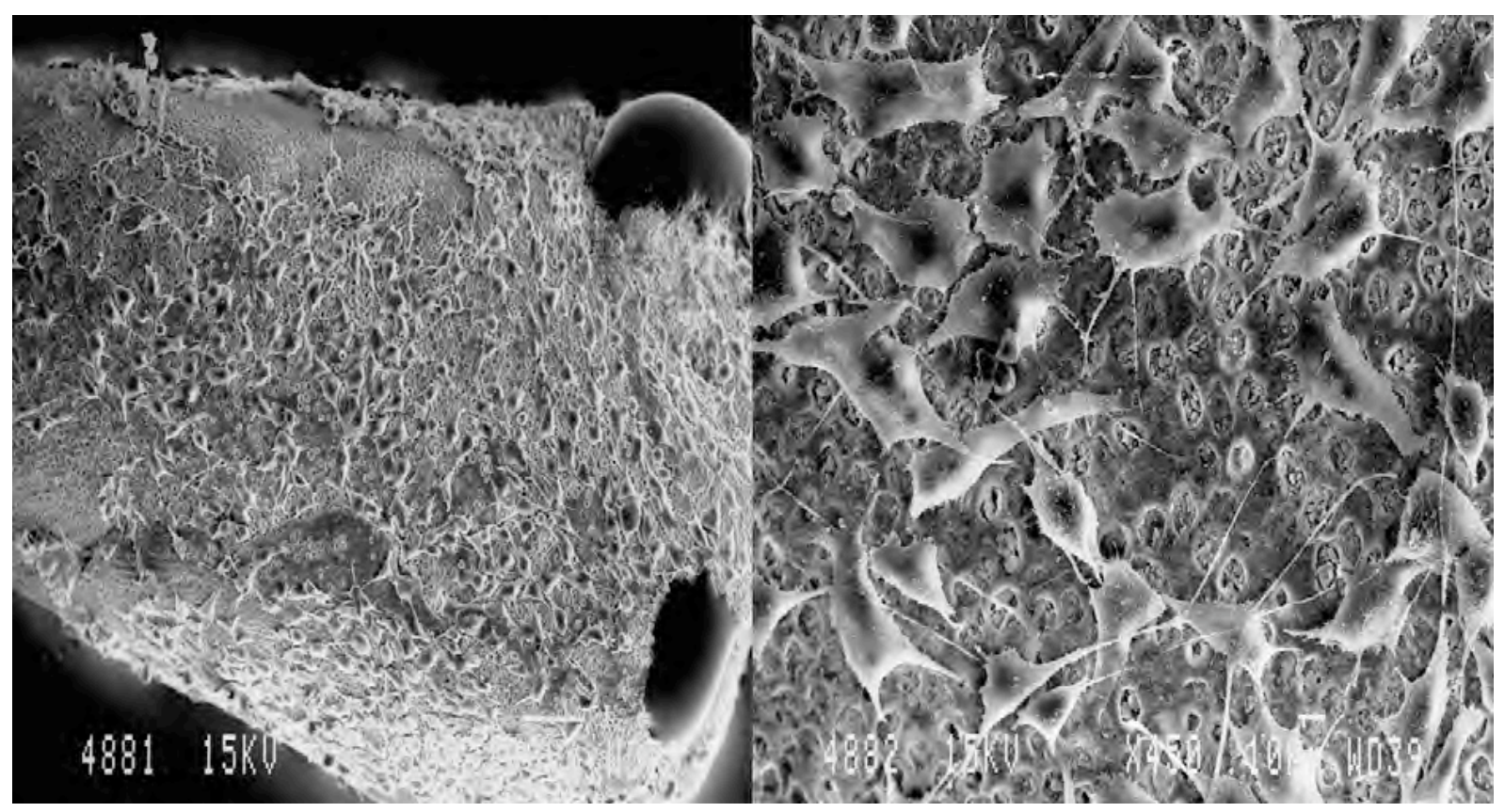

Figure 1 MG63 osteogenic cells seeded at 5,000 cells and cultured for 5 days on a coral based HA (marker bars $=10 \mu \mathrm{m})($ from Kusmanto et al. [15]) 
then decreased with a major drop seen after 8 weeks, whereas with the filled composites the $\mathrm{pH}$ of the solution initially increased slightly and then remained constant. The addition of the filler particles also reduced the degradation as measured by the molecular weight of the polymer phase.

Oliveria et al. [21] used co-precipitation to produce composites of carboxymethylchitosan reinforced with 24 vol\% HA. Wax spheres 50-450 $\mu \mathrm{m}$ in diameter were incorporated to produce the required porosity and the wax was subsequently removed by soaking the scaffolds in tetrahydrofuran which was then removed by freeze drying. Open celled pores $20-500 \mu \mathrm{m}$ across were produced with specimen porosity of nearly $60 \%$ and the scaffolds were shown to be bone bioactive by being coated with an apatitic layer after soaking in SBF. The compressive stiffness and strength were 57.3 and $51.0 \mathrm{MPa}$ respectively.

\section{POROUS MANUFACTURE}

The two most commonly used methods of direct porous manufacture are supercritical processing and freeze-drying directly from a suspension, with newer techniques such as fused deposition and electrostatic spraying becoming more popular.

The group at the National University of Singapore have used fused deposition modelling to manufacture scaffolds of PCL reinforced with
$20 \%$ TCP and subjected these scaffolds to a series of studies [22-24]. The scaffolds are laid down with a $0^{\circ} / 60^{\circ} / 120^{\circ}$ pattern that produces hexagonal channels $600 \mu \mathrm{m}$ across through the scaffolds (Figure 2). They investigated the degradation of the scaffolds and show that they would survive at least 28 days with changes in the $\mathrm{pH}$ of the solution only appearing after 20 days. They have shown these scaffolds to capable of releasing BMP-2 and thus upregulating osteoblasts during the first few postoperative days.

Chen and Boccaccini [25] developed scaffolds of Bioglass ${ }^{\circledR} \quad 45 \mathrm{~S} 5$ reinforced with poly(3hydroxybutyrate) (PHB) by using a slurry of Bioglass ${ }^{\circledR}$ 45S5 to coat polyurethane (PU) foams with either 45 or 60 pores per inch $(25 \mathrm{~mm})$. After sintering the structure consisted of rods of Bioglass ${ }^{\circledR}$ and these scaffolds were then immersed in a solution of PHB in chloroform. After drying the presence of the PHB coating reduced the surface tension. They showed the bioactivity of the scaffolds by the development of an apatitic coating after soaking in SBF for up to 28 days. Finally cells from the HOS-TE85 osteoblast cell line were grown on the scaffolds and showed similar responses to coated and uncoated specimens although the cells did appear to attach better to the PHB coated specimens [26].

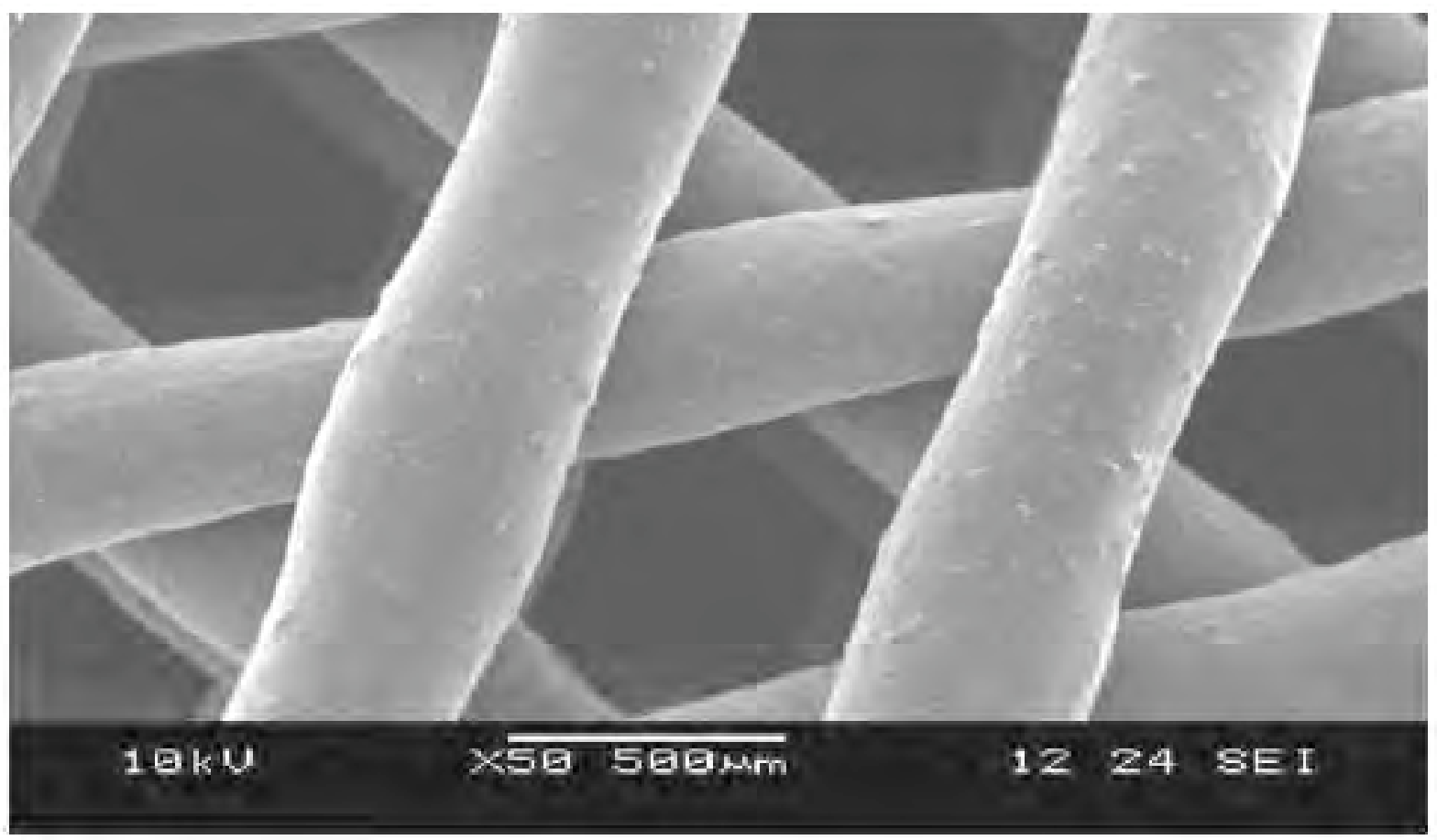

Figure 2 Fused deposition scaffold of PCL-TCP produced by Rai et al. [21] showing the size of the channels produced through the scaffold. Scale bar $=500 \mu \mathrm{m}$. (from Rai et al [21]) 
Liao and Cui and colleagues [27-29] manufactured a composite of nanoHA in type I collagen, they then used this material to reinforce PLLA with the porosity generated by a freeze drying process. The pores were $100-300 \mu \mathrm{m}$ across and the compressive strength was between 13 and 1.9MPa for 8 to $12 \%$ PLLA content, with the compressive modulus between 20 and $45 \mathrm{MPa}$. Both in vitro and in vivo testing showed the material to be biocompatible and bioactive. One method of increasing the mechanical properties is to add reinforcement in the form of fibres or to cross-link the polymeric phase, thus Li et al. [30] took their colleagues's material and added chitosan fibres which in some cases they crosslinked. Increasing the chitosan fibre content from 10 to $50 \mathrm{vol} \%$ lead to a reduction in porosity from 91 to $83 \%$ and the mean pore size from $190 \pm 5 \mu \mathrm{m}$ to $140 \pm 5 \mu \mathrm{m}$. Adding chitosan fibres without any cross-linking increased the modulus from $1.71 \mathrm{MPa}$ to $4.1 \mathrm{MPa}$ at $22 \mathrm{vol} \%$ content, but when the fibres were cross-linked the modulus reached 8.36MPa. Adding the chitosan fibres increased the hydrophilicity of the PLLA/nanoHA/collagen composite and thus attachment of bone marrow derived mesenchymal cells with neglible mechanical effects produced by the cross-linking. Catledge et al. [31] used electrospinning to produce scaffolds of PCL, collagen and PCLcollagen all reinforced with 20 wt $\%$ nanohydroxyapatite. All three composites produced porous scaffolds and nanoindentation after compaction showed that the highest Young's modulus for the fibres was found for the collagennanoHA scaffold followed by the PCL-collagennanoHA.
Heo et al. [32,33] produced nanosized HA and mixed it into a solution of PLA and then used a rapid prototyping system to build up scaffolds of rods of the composite about $300 \mu \mathrm{m}$ in diameter separated by about $500 \mu \mathrm{m}$, with each layer deposited at right angles to the underlying layer in a layer manufacturing process (Figure 3). Micron sized HA based scaffolds were used as controls and the porosity of both scaffolds was $72-73 \%$. Compression testing showed more effective reinforcement by the nanoHA particles as the modulus was $3.2 \pm 0.1 \mathrm{MPa}$ versus $1.3 \pm 0.1 \mathrm{MPa}$ for the macroHA reinforced composite. Contact angle measurements showed the nanoHA reinforced scaffolds to have faster water absorption which correlated with higher MG63 osteoblast cell line attachment from 4 hours to 7 days. SEM showed that the scaffolds produced with the nanoHA were much smoother allowing the cells to spread more extensively. Mesenchymal stem cells were also cultured on both these scaffolds and also proliferated and differentiated more on the nanoHA reinforced scaffolds. The nanoHA reinforced scaffolds were then implanted into critical size defects in rabbit tibiae with nanoHA reinforced scaffolds produced by a more conventional porogen based technique, but with similar porosity, as controls. There was more, and more organised, osteoid deposition in the layer manufactured scaffolds than those produced using the porogen technique. Hong et al. [34] used a similar technique to produce $50 \mathrm{wt} \% \mathrm{HA}$ in PCL scaffolds and showed similar cell viability for rat bone marrow stromal cells, but with increased cell differentiation for the HA-PCL scaffolds than the non-reinforced PCL scaffolds.

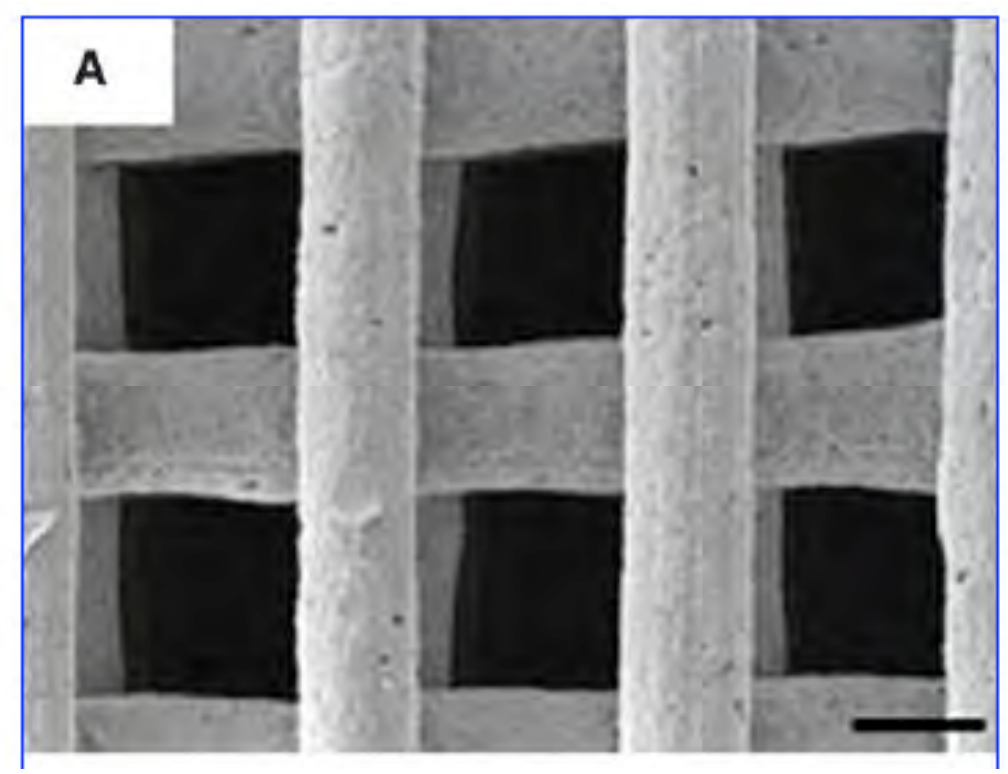

Figure 3 Layer manufactured nanoHA reinforced PLA scaffold produced by Heo et al. [31] showing the pore size to be approximately $500 \mu \mathrm{m}$ and the smooth surface of the material. Marker bar $=300 \mu \mathrm{m}$. (reproduced from Heo et al. [31]) 
Costa et al. [35,36] foamed polyvinyl alcohol (PVA) reinforced with 20 to $40 \mathrm{wt} \%$ of $58 \% \mathrm{SiO}_{2}$ $33 \% \mathrm{CaO}-9 \% \mathrm{P}_{2} \mathrm{O}_{5}$ to produce porous scaffolds. After morphological, chemical and mechanicacharacterisation the scaffolds were cultured with cells from the VERO line. At $30 \mathrm{wt} \%$ glass the effect of increasing the molecular weight of the PVA from 9,000-10,000 to 13,000 $23,000 \mathrm{~g} \mathrm{~mol}^{-1}$ was to increase the stiffness of the scaffold from 2.6 to $5.9 \mathrm{MPa}$, although there was minimal change in the strength, while they comment that the glass alone did not have sufficient mechanical properties to be handled, let alone tested. The cell culture studies showed good cell viability on the composite scaffolds.

Duarte et al. [37] used supercritical processing to produce porous scaffolds of starch-polylactic acid blend reinforced with 0,10 or $15 \mathrm{wt} \%$ Bioglass ${ }^{\circledR}$ 45S5. Dynamic mechanical analysis (DMA) was used to measure the compressive mechanical properties of the scaffolds and showed that the addition of the Bioglass ${ }^{\circledR}$ increased the dynamic stiffness. Soaking in SBF showed the composites to have higher bone bioactivity than the non-filled polymer.

Liu and colleagues [38,39] used PLLA, PLDLA and PGA all reinforced with 30 or $50 \mathrm{wt} \%$ TCP and then used a combination of low temperature deposition to produce macropores or channels through the materials and freeze drying to produce micropores. In a series of purely mechanical tests they optimised the production route. $30 \mathrm{wt} \% \mathrm{TCP}$ gave a stronger material than $50 \mathrm{wt} \%$ TCP for each polymer and using PLLA as the matrix materials lead to the highest mechanical properties at each filler level. They subsequently used a multi-nozzle system to co-deposit PLGA reinforced with $25 \mathrm{wt} \%$ TCP with collagen or chitosan or gelatin to produce biphasic scaffolds. One such scaffold included blood vessel scaffolds laid down through the bone scaffold (Figure 4).

Zhang and Zhang [9] used both $\beta$-TCP and a $\mathrm{CaO}-\mathrm{P}_{2} \mathrm{O}_{5}-\mathrm{TiO}_{2}-\mathrm{Na}_{2} \mathrm{O}$ glass to reinforce chitosan and then freeze drying to generate porosity. Porosities between $75 \%$ and $90 \%$ were achieved with compressive moduli between 1 and $3 \mathrm{MPa}$ and strengths between 0.1 and $0.3 \mathrm{MPa}$. Soaking in SBF showed the materials to be bioactive.

\section{CERAMIC DEPOSITION ON TO POLYMERS}

A bioceramic layer deposited onto a scaffold can be produced by soaking the polymeric scaffold in above physiological strength Simulated Body Fluid (SBF). If the strength of the SBF solution is increased then the rate of deposition is substantially increased and deposition will occur on many non-bioactive materials including porous polymer scaffolds rendering them bioactive. In addition pre-treatment with acid or alkaline solutions may generate apatite nuclei and thus all the deposition on non-bioactive surfaces [6].

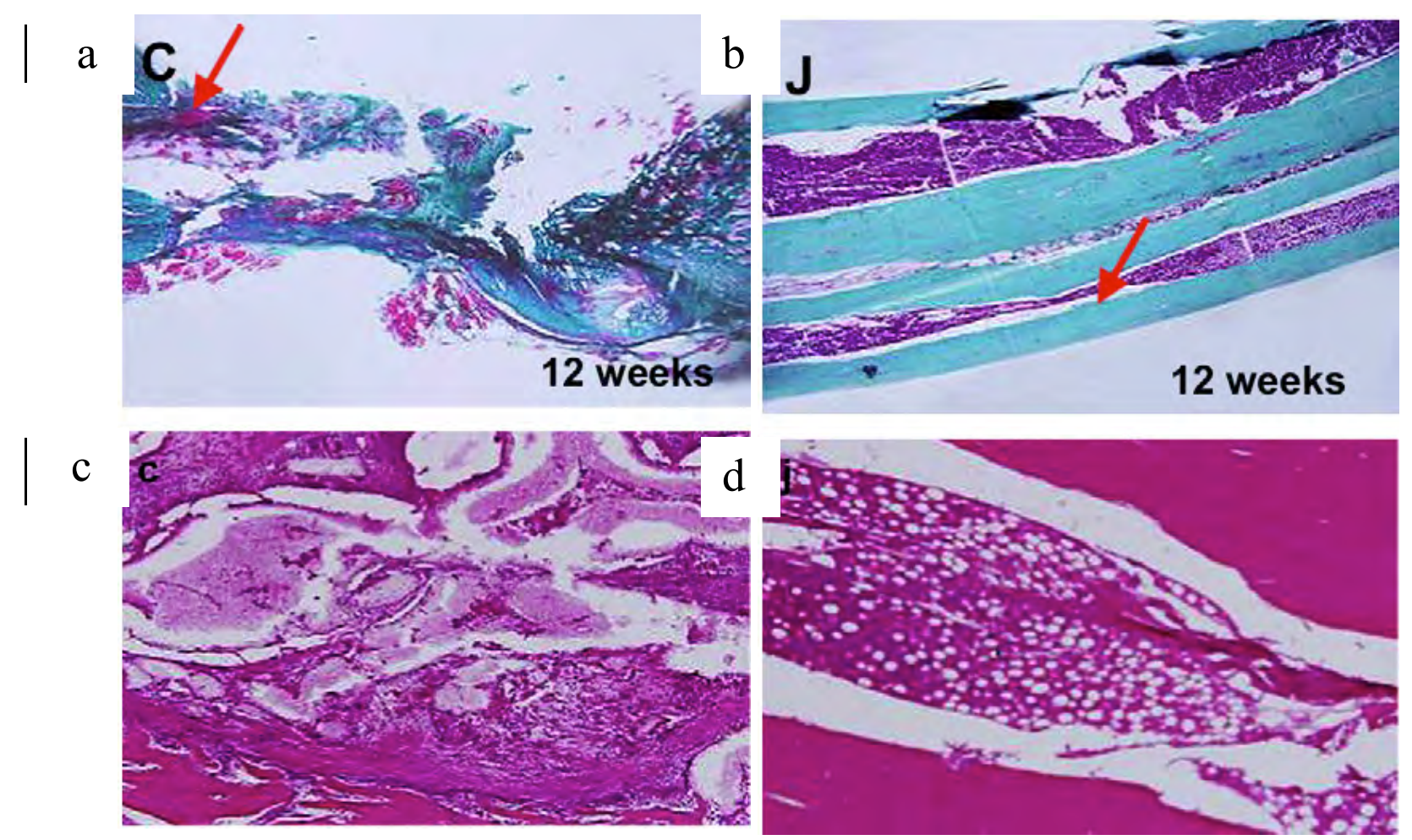

Figure 4 Comparison of the healing after 12 weeks of a skull defect in a rabbit a) \& c) with no implant in the defect and b) \& d) with Gelatin/nano HAP/fibrin scaffold with rhBMP-2 in the defect (magnifications a) \& c) $6 \times$ b) \& d) 100×) (from Liu et al. [38]) 
Al-Munajjed and colleagues [40,41] used freeze drying from a suspension of collagen to produce a $90 \%$ porous collagen scaffold which they then alternately immersed in between 0.1 and $1.0 \mathrm{M}$ strength solutions of calcium chloride $\left(\mathrm{CaCl}_{2}\right)$ and ammonium sodium hydrogen phosphate $\left(\mathrm{NaNH}_{4} \mathrm{HPO}_{4}\right)$ to produce a calcium phosphate coating. They optimised the solution concentrations, soaking times and number of immersions and their order and increased the modulus from 0.27 to $10.3 \mathrm{kPa}$. The coating was shown to be mainly HA with some small amounts of other calcium phosphates. In the second study, they soaked collagen scaffolds for 4 days in SBF at 5 times physiological strength (5SBF) to coat a $99.5 \%$ porous collagen scaffold. The coating process increased the strength from $0.23 \mathrm{kPa}$ to $0.9 \mathrm{kPa}$ and mouse MC3T3-E1 pre-osteoblast cells grown on the scaffolds showed minimal differences in their responses to the coated or noncoated scaffolds.

Douglas et al. [42] produced PLGA scaffolds by a salt leaching process and then soaked the scaffolds in triple strength SBF to produce an apatite coating. No mechanical tests were performed, but cell culture with human osteoblasts showed the scaffolds to be biocompatible.

Jie and $\mathrm{Li}$ [43] precipitated nanoHA into PA66 polyamide (nylon) by dissolving $\mathrm{Ca}\left(\mathrm{NO}_{3}\right)_{2}$ with the polyamide using an organic solvent and then reacting this solution with $\mathrm{Na}_{3} \mathrm{PO}_{4}$. After cleaning the composite scaffold was produced using an injection foaming method. The nanoHA content was between 39 and $64 \mathrm{wt} \%$ and as the nanoHA content increased the elastic modulus increased from $3.6 \pm 0.3 \mathrm{GPa}$ to $5.6 \pm 0.3 \mathrm{GPa}$ and the compressive strength from $93 \pm 7 \mathrm{MPa}$ to $117 \pm 4 \mathrm{MPa}$. XRD, TEM and infrared spectroscopy showed the mineral phase to be nanoparticles of HA. Increasing the nanoHA content, while it increased the porosity from 71 to $80 \%$, also changed the closed cell and open cell macropore content from $9 \%$ and $91 \%$ respectively to $19 \%$ and $81 \%$ respectively, although they do point out that the closed cells were also interconnected by micropores. In subsequent studies they used thermally induced phase separation to produce the porosity and were able to obtain anisotropic pores, leading to up to a factor of two difference in the longitudinal and transverse compressive moduli and strengths and a maximum strength of $550 \mathrm{MPa}$ [44]. However, it seems unlikely that this material will be degradable.

Mavis et al. [45] used electrospinning to produce a mat of nanosized PCL fibres and then soaked this in four of their own recipe 10 times strength
SBFs for between 2 and 15 hours (Figure 5). The deposited particles were found to have $\mathrm{Ca}: \mathrm{P}$ ratios between 1.3 and 1.5 and were therefore thought to be TCP or other various low calcium content CaPs which are expected to degrade fast on implantation. Culture with the MC3T3-E1 cell line showed that the materials were biocompatible and indeed bioactive with the cell activity increased on the coated scaffolds compare to uncoated control scaffolds.

Oyane et al. [46,47] took plain PCL laid down in $0^{\circ} / 60^{\circ} / 120^{\circ}$ pattern to give a hexagonal scaffold by the group from National University of Singapore, then used either $\mathrm{NaOH}$ to produce carboxylate groups on the surface followed by alternate $\mathrm{CaCl}_{2}$ and $\mathrm{K}_{2} \mathrm{HPO}_{4}$ aqueous solutions or oxygen plasma treatment followed by soaking in the same calcium and phosphate salts by dissolved in either water or an ethanol:water mix. Their dipping times were much shorter than the other studies at 10 seconds per dip and only three dips per solution. The $\mathrm{NaOH}$ pre-treatment was found to need 2 or $5 \mathrm{M}$ strength solutions to precondition the surface to allow formation of an
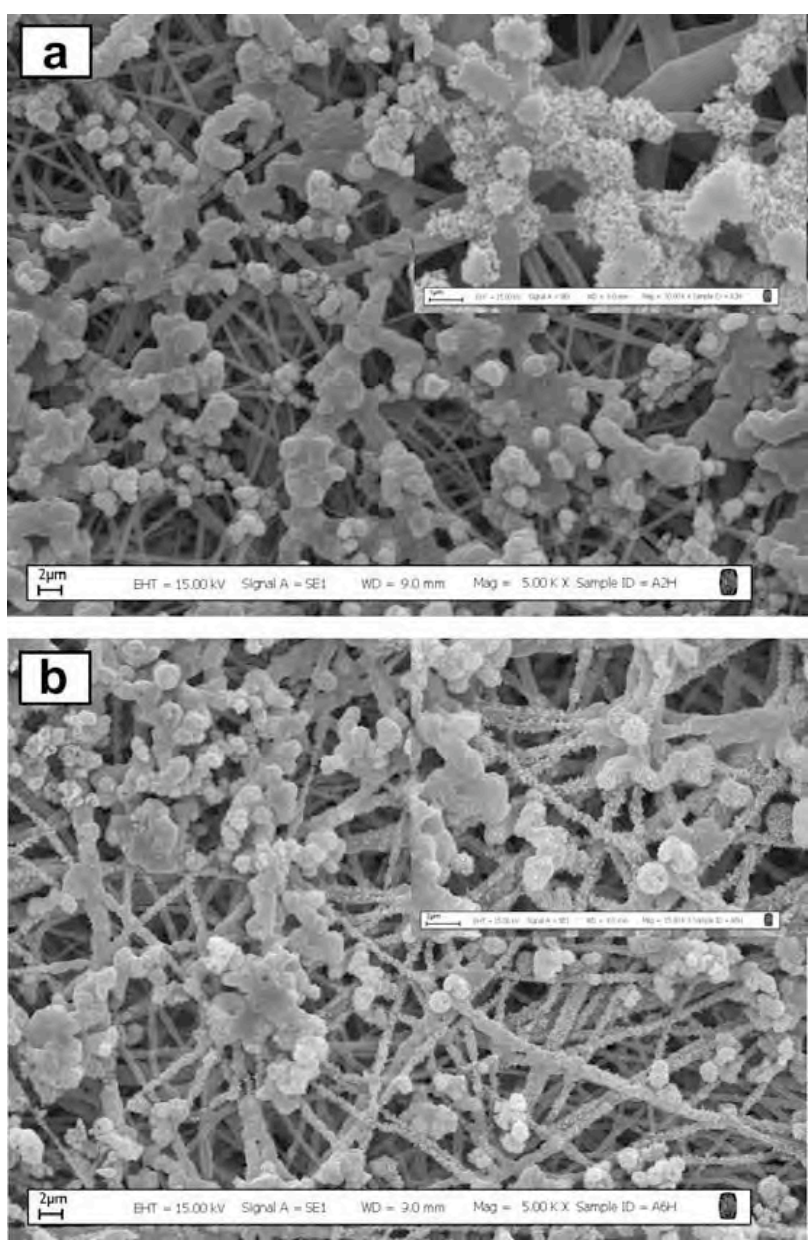

Figure 5 Deposition of apatite crystals on electrospun PCL fibres after soaking in a simulated body fluid for a) 2 and b) 6 hours $($ marker bars $=2 \mu \mathrm{m})($ from Mavis et al. [44]) 
apatite layer after 24 hours in SBF. The oxygen plasma treatment decreased the contact angle, as did the use of ethanol in the solution and with both oxygen plasma treatment and using an ethanol containing solution at $0.2 \mathrm{M}$ strength solutions, they were able to modify the surface such that after 24 hours in SBF the surface was totally covered in apatite.

A different approach was taken by Davies et al. [48] as they used a modified SBF to deposit an apatitic layer on poly(lactide-co-glycolide) microspheres and manufactured these into scaffolds using both the generation of $\mathrm{CO}_{2}$ gas and the use of salt particles as to produce porosity. The layer of apatite deposited on the polymer microspheres was used to incorporate a mineral phase in the material used to manufacture the scaffolds. They used human mesenchymal stem cells to assess the biocompatibility. The scaffolds were found to be osteoconductive, that is bone would grow over the surface if the material was implanted in contact with bone.

PHB with $8 \mathrm{~mol} \%$ PHV was manufactured into porous scaffolds using salt as a porogen by Huang et al. [49]. After the salt was leached out and the samples dried, they were soaked in $\mathrm{Ca}(\mathrm{OH})_{2}$ solution for one week, to produce apatite nucleation sites, and then in alternating solutions. After seven cycles of soaking in $100 \mathrm{mM} \mathrm{CaCl}_{2}$ in Tris for 24 hours followed by $100 \mathrm{mM} \mathrm{Na}_{2} \mathrm{HPO}_{4}$ in Tris for 24 hours, with the samples washed between each solution. SEM and XRD showed that nanoparticles of apatite had been deposited in a continuous layer over the surface.

A similar pair of solutions was used by Matsusaki et al. [50] who produced a scaffold of extracellular matrix including mesenchymal stem cells and then soaked this alternately in $\mathrm{CaCl}_{2}$ in $50 \mathrm{mM}$ Tris- $\mathrm{HCl}$ buffer and in $\mathrm{Na}_{2} \mathrm{HPO}_{4}$ in $50 \mathrm{mM}$ Tris-HCl buffer for 10 seconds each with a $10 \mathrm{~s}$ wash in plain $50 \mathrm{mM}$ Tris- $\mathrm{HCl}$ buffer between each active solution. The strengths of each of the $\mathrm{CaCl}_{2}$ and $\mathrm{Na}_{2} \mathrm{HPO}_{4}$ solutions was varied between 10 and $200 \mathrm{mM}$ and either 10 or 20 soak cycles were used. The scaffolds were characterised by FTIR and live/dead staining of the cells that went through the alternating soak cycles. At 10 and $50 \mathrm{mM}$ strength the number of live cells was not statistically reduced, but above these strengths there was a decrease in the number of live cells.

\section{POLYMER DEPOSITION ON TO CERAMICS}

Kim et al. [48] coated scaffolds of HA with an HA/PCL composite doped with tetracycline hydrochloride antibiotic as a drug delivery system. The HA scaffold was dip coated with between 20 and $80 \mathrm{wt} \%$ HA in PCL. The compressive stiffness and strength increased from $0.79 \pm 0.04 \mathrm{MPa}$ to $1.43 \pm 0.2 \mathrm{MPa}$ and from $0.16 \pm 0.04 \mathrm{MPa}$ to $0.45 \pm 0.04 \mathrm{MPa}$ respectively when the maximum amount of $50 \mathrm{wt} \%$ HA coating was applied. Initially the drug release was fast and then slowed, but continued up to 7 days.

Abarrategi et al. [49] deposited chitosan onto $\beta$ TCP discs. The discs were produced by mixing $\beta$ TCP, calcium phosphate and calcium carbonate with a solution of acetic acid. Pores were generated by the calcium carbonate-acetic acid interaction which produced $\mathrm{CO}_{2}$. Once the discs had set, been sterilised, washed in medium and dried they were either coated with chitosan containing recombinant human bone morphogenic protein-2 (rhBMP-2) or allowed to absorb the rhBMP-2 directly into their surfaces. The manufacturing process produced discs that were just over $50 \%$ porous and the porosity was reduced to approximately $47 \%$ by the chitosan coating although the process did alter the distribution of pore sizes. The production process gradually increased the strength from the "green" discs to the sterilised and washed discs at $8.30 \mathrm{MPa}$ and after chitosan coating to $11.28 \mathrm{MPa}$. After cell culture the devices were implanted $8 \mathrm{~mm}$ diameter defects in the skulls of rabbit. The discs coated in plain chitosan and those with absorbed rhBMP-2 but no chitosan produced "good bone response" after 3 weeks, but those coated with chitosan containing rhBMP-2 were totally covered with new bone.

Cao et al. [50] used sol-gel processing to produce porous $\mathrm{A}-\mathrm{W}$ glass-ceramic porous scaffolds and then coated these with chitosan. The chitosan coating increased the strength by a factor of over 8 , bringing the strength into the range for cancellous bone, but reduced the bone bioactivity as measured using soaking in SBF, however osteoblast cell adhesion was still good.

Mantos et al. [51] used a polyurethane model to produce porous scaffolds of $50 \% \mathrm{SiO}_{2}-22.6 \% \mathrm{CaO}-$ $5.9 \% \mathrm{Na}_{2} \mathrm{O}-4 \% \mathrm{P}_{2} \mathrm{O}_{5}-12 \% \mathrm{~K}_{2} \mathrm{O}-5.3 \% \mathrm{MgO}-$

$0.2 \% \mathrm{~B}_{2} \mathrm{O}_{3}$ glass and then dip coated these in PLDLA to produce a $1-5 \mu \mathrm{m}$ thick layer. The coating covered all the struts of the scaffold and increased the strength from $0.4 \mathrm{MPa}$ to $0.6 \mathrm{MPa}$. The porosity ranged from $61 \%$ to $73 \%$ with the average pore size between $250 \mathrm{~m}$ to $300 \mu \mathrm{m}$, soaking in SBF for only 3 days lead to the production of an HCA layer on the scaffolds.

\section{CHARACTERISATION OF THE SCAFFOLDS}

Georgiou et al. [52] manufactured scaffolds of PLA reinforced with $46 \% \mathrm{CaO}-4 \% \mathrm{Na}_{2} \mathrm{O}-50 \% \mathrm{P}_{2} \mathrm{O}_{5}$ glass, with the porosity produced using supercritical $\mathrm{CO}_{2}$. DMA testing showed the 
storage modulus of the solid material was increased from 4.4 to $5.2 \mathrm{GPa}$ by the addition of $20 \mathrm{wt} \%$ glass. However, the material and material porosity were inhomogeneous at this filler level. The ion release rate depended on the glass content. Culturing of human fetal bone cells showed the material to be biocompatible.

Gelsinsky et al. [53] manufactured porous scaffolds of collagen type I reinforced by HA and then generated porosity using a freeze-drying process. Their production technique [54] resulted in the simultaneous reassembly of the collagen fibrils and precipitation of nanoparticles of HA. After the freeze drying process the scaffolds were cross-linked. The pores produced were approximately $200 \mu \mathrm{m}$ in diameter and thermogravimetric measurement showed the composite to be approximately $66 \mathrm{wt} \%$ HA. FTIR confirmed the presence of collagen type I and HA and micro CT showed the porosity to be about $72 \%$ with a mean pore diameter of $180 \pm 12 \mu \mathrm{m}$. The compressive strength when swollen in water was $14 \mathrm{MPa}$ at $20 \%$ strain and $23.5 \mathrm{MPa}$ at $40 \%$ strain. After 14 days culture viable human marrow stromal cells were found throughout the scaffold although there were more at the edges than in the centre.

\section{IN VITRO TESTING OF SCAFFOLDS}

Haimi et al. [55] cultured human adipose stem cells on PLA reinforced with between 0 and 20 $\mathrm{wt} \%$ of either $\beta$-TCP or a bioactive glass based on $5 \% \mathrm{Na}_{2} \mathrm{O}-7.5 \% \mathrm{~K}_{2} \mathrm{O}-3 \% \mathrm{MgO}-25 \% \mathrm{CaO}-$

$59.5 \% \mathrm{SiO}_{2}$ with porosity produced by freeze drying. After 2 weeks, compared to nonreinforced PLA scaffolds, statistically more cells were seen on the scaffolds reinforced with $\beta$-TCP and statistically less on the scaffolds reinforced with the bioactive glass. Higher alkaline phosphatase activity was seen on the $\beta$-TCP reinforced scaffolds after both 1 and 2 weeks, with no difference between the non-reinforced PLA scaffold and that reinforced with the bioactive glass.

\section{IN VITRO CELL SEEDING ONTO COMPOSITE SCAFFOLDS}

Blaker et al. [56] and Maquet et al. [57] used freeze drying to produce porosity in a composite of PDLLA reinforced with Bioglass $\AA 45 \mathrm{~S} 5$ with a mean particle size of $>5 \mu \mathrm{m}$, at either 5 or $40 \mathrm{wt} \%$ Bioglass $\AA$. Cell culture was performed using the human osteosarcoma cell line MG-63. The mean macropore size was $100 \mu \mathrm{m}$ interconnected via micropores of $10-50 \mu \mathrm{m}$, with scaffold anisotropy. Soaking in physiological strength SBF showed the materials to be bioactive in vitro. Surprisingly the cell culture showed similar numbers of osteoblasts in the scaffolds for scaffolds containing either 5 or $40 \mathrm{wt} \%$ Bioglass $\AA$ although in both these cases this was more than on the plain PDLLA scaffolds. Cai et al. [57] used a combination of alginate and gelatine reinforced with TCP to produce scaffolds. They varied the degree of oxidation of the alginate to change the properties but found that neonatal rat calvaria osteoblasts were able to grow on the materials. Furthermore they showed that the material could be used for drug release.

\section{IN VIVO TESTING OF SCAFFOLDS}

Dutta Roy et al. [58] used a three dimensional printing process to produce scaffolds of two different molecular weight PLGA reinforced with $20 \mathrm{wt} \% \beta$-TCP with or without internal channels, but all made porous by the incorporation of salt crystals. These scaffolds were implanted into the skulls of New Zealand White rabbits for eight weeks in sub-critical size defects. Both types of the low molecular weight implants collapsed into the defects with minimal new bone formation, however using the higher molecular weight polymer, the implants survived the implantation with some new bone formation seen in the channels, however the amount of new bone formed was less than with autograph.

Dawson et al. [59] cultured human bone marrow stromal cells on scaffolds of collagen type 1 reinforced with $70 \mathrm{wt} \%$ carbonated $\mathrm{HA}$ (cHA) produced by Sachlos et al. [60] using a freeze drying process prior to subcutaneous implantation and compared with collagen type I scaffolds without cHA. The mean pore size in the composite scaffolds was $165 \mu \mathrm{m}$ in the composite scaffold and less than $64 \mu \mathrm{m}$ in the collagen. These pore sizes were deliberate to produce a biphasic material that would encourage bone ingrowth in the composites and cartilage regeneration in the collagen scaffold thus allowing the repair of osetocondral defects. They found that the composite scaffold supported osteogenesis in vitro although they did have difficulties in differentiating between newly formed collagen and that of the scaffolds. The human bone marrow stromal cells had penetrated into the scaffolds with high levels of alkaline phosphatase activity. In vivo studies were performed by seeding the collagen HA scaffolds followed by cell culture for 72 hours and then implanting subcutaneously for 4 weeks or seeding and culturing for 48 hours and then implanting into a defect in the mouse femur. Subcutaneous implantation lead to osteoid formation and good integration was seen with the bony defects. 


\section{DISCUSSION}

While many scaffolds have been produced only a few have the appropriate pore sizes of both 300$400 \mu \mathrm{m}$ across macropores and communicating micropores. However, the use of composite production techniques has allowed the increase of the properties by suitable processing technologies. The biological activities have been measured using three major types of tests, soaking in a simulated body fluid to see if an hydrated apatite layer is produced, indicative of the likelihood of a similar process occurring in vivo, cell culture to both ensure that the material produced is not cytotoxic and more importantly to show the bone cells be they primary cell culture or immortalised cell lines are up regulated again indicating an expected similar beneficial response in vivo and finally in vivo testing. Many show appropriate levels of porosity and bioactivity, but the major cause of failure of these scaffolds is the mechanical properties (Table 1) particularly when compared to the properties of natural cancellous bone [65]. The use of perfusion and similar techniques leads to improved cell distribution.

\section{CONCLUSIONS}

While a range of possible materials have been developed and tested, as yet none of them fulfil all the requirements of a bone tissue engineering scaffold. In general the mechanical properties are below those of human cancellous bone and are thus unable to provide even minimal mechanical support. However, many of these materials have been show to be bone bioactive using tests from soaking in simulated body fluid through to in vivo implantation, although their use in critical size defects has not as yet been reported. It seems likely that in the next few years the production of improved bone cell scaffolds will provide both the mechanical properties and required biological activity.

\section{REFERENCES}

1. Whang, K., Healy, K. E., Elenz, D. R., Nam, E. K., Tsai, D. C., Thomas, C. H., Nuber, G. W., Glorieux, F. H., Travers, R. and Sprague, S. M., Engineering bone regeneration with bioabsorbable scaffolds with novel microarchitecture. Tissue Eng. 1999, 5, 35-51.

2. Zhang, C., Hu, Y. Y., Cui, F. Z., Zhang, S. M., Ruan, D. K., A study on tissue engineered bone using rhBMP-2 induced periosteal cells with a porous nanohydroxyapatite/collagen/poly(L-lactic acid) scaffold, Biomed. Mater. 2004, 1, 6562.
3. Hing K. A., Best, S. M., Tanner, K. E., Bonfield, W. and Revell, P. A., Mediation of Bone Ingrowth in Porous Hydroxyapatite Bone Graft Substitutes, J. Biomed. Mat. Res. A, 2004, 68A, 187-200.

4. Bonfield, W., Grynpas, M., Tully, A. E., Bowman, J. and Abram, J., Hydroxyapatite reinforced polyethylene - A mechanically compatible implant materials for bonereplacement, Biomaterials 1981, 2, 185-186.

5. Kokubo, T., Kushitani, H., Sakka, S., Kitsugi, T. and Yamamuro T., Solutions able to reproduce in vivo surface-structure changes in bioactive glass ceramic A-W3. $J$. Biomed. Mater. Res. 1990, 24, 721-734.

6. Huang, J., Di Silvio, L., Wang, M., Tanner, K. E. and Bonfield, W., In Vitro Mechanical and Biological Assessment of Hydroxyapatite-Reinforced Polyethylene Composite, J. Mat. Sci.: Mat. in Med. 1997, 8, 775-779

7. Pino, M., Stingelin, N., Tanner, K.E. Nucleation and Growth of Apatite on $\mathrm{NaOH}$ Treated PEEK, HDPE and UHMWPE for Artificial Cornea Materials, Acta Biomaterialia, 2008, 4, 1827-1836

8. Fratzl, P., Collagen: Structure and Mechanics, an Introduction, $\mathrm{Cpt} 1$ in "Collagen: Structure and Mechanics", Ed P. Fratzl, Pub Springer, 2008.

9. Zhang, Y., Zhang, M. Q., Synthesis and characterization of macroporous chitosan/calcium phosphate composite scaffolds for tissue engineering, J. Biomed. Mat. Res., 2001, 55, 304-312.

10. Muzzarelli, R., Baldassarre, V., Conti, F., Ferrara, P., Biagini, G., Gazzanelli, G., Vasi, V., Biological-activity of Chitosan Ultrastructural-study, Biomaterials, 1989, 9, 247-252.

11. Charles-Harris, M., del Valle, S., Hentges, E., Bleuet, P., Lacroix, D. and Planell, J. A., Mechanical and structural characterisation of completely degradable polylactic acid/calcium phosphate glass scaffolds, Biomaterials, 2007, 28, 4429-443

12. Charles-Harris, M., Navarro, M., Engel, E., Aparicio, C., Ginebra, M. P. and Planell, J. A., Surface characterization of completely degradable composite scaffolds, J. Mat. Sci.: Mat. in Med. 2005, 16, 11251130.

13. Charles-Harris, M., Koch, M.A., Navarro, M., Lacroix, D., Engel, E., Planell, J.A., A PLA/calcium phosphate degradable composite material for bone tissue engineering: an in vitro study, J. Mat. Sci.: Mat in Med., 2008, 19, 1503-1513. 
14. Thompson, I. D. and Hench, L. L., Mechanical properties of bioactive glasses, glass-ceramics and composites Proc. I. Mech. E.: Part H, J., Eng. in Med.1998, 212H, 127-136.

15. Deb, S., Wang, M., Tanner, K. E., Bonfield, W. Hydroxyapatite-polyethylene composites: Effect of grafting and surface treatment of hydroxyapatite. J. Mater. Sci. Mater. Med., 1996, 7, 191-193.

16. Kusmanto, F., Walker, G., Gan, Q., Walsh, P., Buchanan, F., Dickson, G., McCaigue, M., Maggs, C. and Dring, M., Development of composite tissue scaffolds containing naturally sourced microporous hydroxyapatite. Chem. Eng. J., 2008, 139, 398-407.

17. Kim, S. S., Park, M. S., Jeon, O., Choi, C. Y., and Kim, B. S., Poly(lactide-coglycolide)/hydroxyapatite composite scaffolds for bone tissue engineering. Biomaterials, 2006, 27,1399-1409.

18. Guarino, V. and Ambrosio, L., The synergic effect of polylactide fiber and calcium phosphate particle reinforcement in poly epsilon-caprolactone-based composite scaffolds Acta Biomat., 2008, 4, 1778-1787.

19. Li, H. Y., Du, R. L. and Chang, J., Fabrication, characterization, and in vitro degradation of composite scaffolds based on PHBV and bioactive glass. J. Biomat. Appl., 2005, 20, 137-155.

20. Li, H. Y. and Chang, J., In vitro degradation of porous degradable and bioactive PHBV/Wollastonite composite scaffolds. Polymer Degrad. \& Stability, 2005, 87, 301307.

21. Oliveira, J. M., Costa, S. A., Leonor, I. B., Malafaya, P. B., Mano, J. F., and Reis, R. L., Novel

hydroxyapatite/carboxymethylchitosan composite scaffolds prepared through an innovative "autocatalytic" electroless coprecipitation route. J. Biomed. Mat. Res. A, 2009, 88A, 470-480.

22. Rai, B., Teoh, S. H., Ho, K. H., Hutmacher, D.W., Cao, T., Chen, F. and Yacob F., The effect of rhBMP-2 on canine osteoblasts seeded onto 3D bioactive polycaprolactone scaffolds. Biomaterials, 2004, 25, 5499-5506.

23. Chim, H., Hutmacher, D. W., Chou, A. M., Oliveira, A. L., Reis, R. L., Lim, T. C. and Schantz J. T., A comparative analysis of scaffold material modifications for loadbearing applications in bone tissue engineering. Int $J$ Oral \& Maxillofacial Surg., 2006, 35, 928-934.
24. Lei, Y., Rai, B., Ho, K. H. and Teoh, S. H., In vitro degradation of novel bioactive polycaprolactone-20\% tricalcium phosphate composite scaffolds for bone engineering. Mat. Sci. \& Eng. C - Biomimetic \& Supramolecular Systems, 2007, 27, 293-298.

25. Chen, Q. Z., and Boccaccini, A. R., Coupling mechanical competence and bioresorbability in Bioglass $\AA$-derived tissue engineering scaffolds. Adv. Eng. Mater., 2006, 8, 285-289.

26. Bretcanu, O., Misra, S., Roy, I., Renghani, C., Fiori, F., Boccaccini, A. R. and Salih, V., In vitro biocompatibility of $45 \mathrm{~S} 5$ Bioglass $($ derived glass-ceramic scaffolds coated with poly(3-hydroxybutyrate). J. Tissue Eng. \& Reg. Med., 2009, 3, 139-148.

27. Liao, S. S. and Cui, F. Z., In vitro and in vivo degradation of mineralized collagenbased composite scaffold: Nanohydroxyapatite/collagen/poly(Llactide). Tissue Eng., 2004, 10, 73-80.

28. Liao, S. S., Cui, F. Z., Zhang, W., and Feng, Q. L., Hierarchically biomimetic bone scaffold materials: Nano-HA/collagen/PLA composite. J. Biomed. Mat. Res. B - Appl. Biomat., 2004, 69B, 158-165.

29. Liao, S. S., Cui, F. Z., Zhu, Y., Osteoblasts adherence and migration through threedimensional porous mineralized collagen based composite: nHAC/PLA. J Bioactive \& Compatible Polymers, 2004, 19, 117-130.

30. Li, X. M., Feng, Q. L., Wang, W. J., and Cui, F. Z., Chemical characteristics and cytocompatibility of collagen-based scaffold reinforced by chitin fibers for bone tissue engineering. J. Biomed. Mat. Res. B-App. Biomat., 2006, 77B, 219-226.

31. Catledge, S. A., Clem, W. C., Shrikishen, N., Chowdhury, S., Stanishevsky, A. V., Koopman, M. and Vohra, Y. K., An electrospun triphasic nanofibrous scaffold for bone tissue engineering. Biomed Mat., 2007, 2, 142-150.

32. Heo, S. J., Kim, S. E., Wei, J., Hyun, Y. T., Yun, H. S., Kim, D. H., Shin, J. W., and Shin, J. W., In vitro and animal study of novel nano-hydroxyapatite/poly(epsiloncaprolactone) composite scaffolds fabricated by layer manufacturing process. Tissue Eng. A, 2009, 15, 977-989.

33. Heo, S.J., Kim, S.E., Wei, J., Kim, D. H., Hyun, Y. T., Yun, H. S., Kim, H. K., Yoon, T. R., Kim, S. H., Park, S. A., Shin, J. W., and Shin, J. W., Fabrication and characterization of novel nano- and microHA/PCL composite scaffolds using a 
modified rapid prototyping process. $J$. Biomed. Mat. Res. A, 2009, 89A, 108-116.

34. Hong, S. J., Jeong, I., Noh, K. T., Yu, H. S., Lee, G. S., Kim, H. W., Robotic dispensing of composite scaffolds and in vitro responses of bone marrow stromal cells. J. Mat. Sci.: Mat in Med., 2009, 20, 19551962.

35. Costa, H. S., Rocha, M. F., Andrade, G. I., Barbosa-Stancioli, E.F., Pereira, M. M., Orefice, R.L., Vasconcelos, W. L., Mansur, H. S., Sol-gel derived composite from bioactive glass-polyvinyl alcohol. J. Mat. Sci., 2008, 43, 494-502.

36. Mansur, H. S. and Costa, H. S. Nanostructured poly(vinyl alcohol)/bioactive glass and poly (vinyl alcohol)/chitosan/bioactive glass hybrid scaffolds for biomedical applications. Chem Eng. J., 2008, 137, 72-83.

37. Duarte, A. R. C., Caridade, S. G., Mano, J. F. and Reis, R. L.,. Processing of novel bioactive polymeric matrixes for tissue engineering using supercritical fluid technology. Mat. Sci. \& Eng. C-Mat. Biological Appl., 2009, 29, 2110-2115.

38. Liu, L., Xiong, Z., Yan, Y. N., Hu, Y. Y., Zhang, R. J. and Wang, S. G., Porous morphology, porosity, mechanical properties of poly(alpha-hydroxy acid)-tricalcium phosphate composite scaffolds fabricated by low-temperature deposition. J. Biomed. Mat. Res. A, 2007, 82A, 618-629.

39. Liu, L., Xiong, Z., Yan, Y. N., Zhang, R. J., Wang, X. H. and Jin, L., Multinozzle Low-Temperature Deposition System for Construction of Gradient Tissue Engineering Scaffolds. J. Biomed. Mat. Res. B-App. Biomat., 2009, 88B, 254-263.

40. Al-Munajjed, A. A., and O'Brien, F. J., Influence of a novel calcium-phosphate coating on the mechanical properties of highly porous collagen scaffolds for bone repair. J. Mech. Behavior Biomed, Mat., 2009, 2, 138-146.

41. Al-Munajjed, A. A., Plunkett, N. A., Gleeson, J. P., Weber, T., Jungreuthmayer, C., Levingstone, T., Hammer, J., and O'Brien, F. J., Development of a biomimetic collagenhydroxyapatite scaffold for bone tissue engineering using a SBF immersion technique. J. Biomed. Mat. Res. B - App. Biomat., 2009, 90B, 584-59 .

42. Douglas, T., Pamula, E., Hauk, D., Wiltfang, J., Sivananthan, S., Sherry, E. and Warnke, P. H., Porous polymer/hydroxyapatite

scaffolds: characterization and biocompatibility investigations J. Mat. Sci.: Mat in Med., 2009, 20, 1909-1915.

43. Jie, W. and Li, Y. B., Tissue engineering scaffold material of nano-apatite crystals and polyamide composite. Euro Polymer J., 2004, 40, 509-515.

44. Wang, H. N., Zuo, Y., Zou, Q., Cheng, L., Huang, D., Wang, L. and Li, Y. B., NanoHydroxyapatite/Polyamide66 Composite Tissue-Engineering Scaffolds with Anisotropy in Morphology and Mechanical Behaviors, J. Poly. Sci.: A: Poly. Chem., 2009, 47, 658-669.

45. Mavis, B., Demirtas, T. T., Gümüsderelioglu, M., Gündüz, G. and Colak, Ü., Synthesis, characterization and osteoblastic activity of polycaprolactone nanofibers coated with biomimetic calcium phosphate. Acta Biomat., 2009, 5, 30983111.

46. Oyane, A., Uchida, M., Choong, C., Triffitt, J., Jones, J. and Ito, A. Simple surface modification of poly( $\varepsilon$-caprolactone) for apatite deposition from simulated body fluid. Biomaterials, 2005, 26, 2407-2413.

47. Oyane, A., Uchida, M., Yokoyama, Y., Choong, C., Triffitt, J. and Ito, A. Simple surface modification of poly( $\varepsilon$-caprolactone) to induce its apatite-forming ability. $J$. Biomed. Mat. Res. A, 2005, 75A, 138-145.

48. Davis, H. E., Rao, R. R., He, J. W., and Leach, J.K., Biomimetic scaffolds fabricated from apatite-coated polymer microspheres. $J$. Biomed. Mat. Res. A, 2009, 90A, 1021-1031.

49. Huang, C. P., Chen, X. M. and Chen, Z. Q., Biomimetic construction of poly(3hydroxybutyrate-co-3-

hydroxyvalerate)/apatite composite materials by an alternate incubation process. Mat. Letters, 2008, 62, 1499-1502.

50. Matsusaki, M., Kadowaki, K., Tateishi, K., Higuchi, C., Ando, W., Hart, D. A., Tanaka, Y., Take, Y., Akashi, M., Yoshikawa, H., and Nakamura, N., Scaffold-Free Tissue-Engineered ConstructHydroxyapatite Composites Generated by an Alternate Soaking Process: Potential for Repair of Bone Defects. Tissue Eng. A, 2009, 15, 55-63.

51. Kim, H. W., Knowles, J. C. and Kim H. E., Hydroxyapatite/poly(e-caprolactone) composite coatings on hydroxyapatite porous bone scaffold for drug delivery, Biomaterials, 2004, 25, 1279-1287.

52. Abarrategi, A., Moreno-Vicente, C., Ramos, V., Aranaz, I., Sanz Casado, J.V. 
and Lopez-Lacomba, J.L., Improvement of porous beta-TCP scaffolds with rhBMP-2 chitosan carrier film for bone tissue application. Tissue Eng. A, 2008, 14, 13051319.

53. Cao, B., Zhou, D., Xuen M., Li, G. D., Yang, W. Z., Long, Q. and Ji, L., Study on surface modification of porous apatitewollastonite bioactive glass ceramic scaffold. Appl. Surface Sci., 2008, 255, 505-508.

54. Mantsos, T., Chatzistavrou, X., Roether, J. A., Hupa, L., Arstila, H. and Boccaccini, A R., Non-crystalline composite tissue engineering scaffolds using boron-containing bioactive glass and poly(D,L-lactic acid) coatings. Biomed. Materials, 2009, 4, Number: 055002.

55. Georgiou, G., Mathieu, L., Pioletti, D.P., Bourban, P.-E., Manson, J.-A. E., Knowles, J.C. and Nazhat, S.N., Polylactic acid-phosphate glass composite foams as scaffolds for bone tissue engineering, $J$. Biomed. Mat. Res. B. (Appl. Biomat.), 2007, 80B, 322-331.

56. Gelinsky, M., Welzel, P. B., Simon, P., Bernhardt, A. and König, U., Porous threedimensional scaffolds made of mineralised collagen: Preparation and properties of a biomimetic nanocomposite material for tissue engineering of bone. Chem Eng. J., 2008, 137, 84-96.

57. Bradt, J.-H., Mertig, M., Teresiak, A. and Pompe, W., Biomimetic mineralization of collagen by combined fibril assembly and calcium phosphate formation, Chem. Mater. 1999, 11, 2694-2701.

58. Haimi, S., Suuriniemi, N., Haaparanta, A.M., Ella, V., Lindroos, B., Huhtala, H., Räty, S., Kuokkanen, H., Sándor, G. K., Kellomäki, M., Miettinen, S. and Suuronen, R., Growth and osteogenic differentiation of adipose stem cells on PLA/bioactive glass and PLA/beta-TCP scaffolds. Tissue Eng. A, 2009, 15, 14731480.

59. Blaker, J. J., Gough, J. E., Maquet, V., Notingher, I. and Boccaccini, A. R., In vitro evaluation of novel bioactive composites based on Bioglass ${ }^{\circledR}$-filled polylactide foams for bone tissue engineering scaffolds, $J$. Biomed. Mat. Res. A, 2003, 67A, 1401-1411.

60. Maquet, V., Boccaccini, A.R., Pravata, L., Notingher, I., Jérôme, R., Preparation, characterisation and in vitro degradation of bioresorbable and bioactive composites based on Bioglass ${ }^{\circledR}$-filled polylactide foams. J Biomed Mater Res A, 2003, 66A, 335-346
61. Cai, K., Zhang, J., Deng, L.H., Yang, L., Hu Y., Chen C., Xue, L. and Wang, L., Physical and biological properties of a novel hydrogel composite based on oxidized alginate, gelatin and tricalcium phosphate for bone tissue engineering. Adv. Eng. Mat., 2007, 9, 1082-1088.

62. Dutta Roy, T., Simon, J. L., Ricci, J. L., Rekow, E. D., Thompson, V. P. and Parsons, J.R., Performance of degradable composite bone repair products made via three-dimensional fabrication techniques, $J$. Biomed. Mat. Res. A, 2003, 66A, 283-291.

63. Dawson, J. I., Wahl, D. A., Lanham, S. A., Kanczler, J. M., Czernuszka, J. T. and Oreffo, R. O. C., Development of specific collagen scaffolds to support the osteogenic and chondrogenic differentiation of human bone marrow stromal cells. Biomaterials, 2008, 29, 3105-3116.

64. Sachlos, E., Gotora, D., and Czernuszka, J. T., Collagen scaffolds reinforced with biomimetic composite nano-sized carbonatesubstituted hydroxyapatite crystals and shaped by rapid prototyping to contain internal microchannels. Tissue Eng. 2006, 12, 2479-2487.

65. Hodgskinson, R., Currey, J.D. Young's modulus, density and material properties in cancellous bone over a large density range. $J$. Mater. Sci., Mater. Med., 1992, 3, 377-381.

66. Liu, Y., Lu, Y., Tian, X.Z., Cui, G., Zhao, Y.M., Yang. Q., Yu S.L., Xing G.S., Zhang B., Segmental bone regeneration using an rhBMP-2-loaded gelatin/nanohydroxyapatite/fibrin scaffold in a rabbit model. Biomaterials, 2009, $306276-$ 6285 . 